\title{
To Study the Efficacy of Yashtimadhuk Tail Pratimarsha Nasya In the management of Khalitya
}

\author{
Research Article
}

\section{Mamata Prataprao Tirankar ${ }^{*}$}

1. Assistant Professor, Department Swasthavritta, S.A.M.C.H Indore.

\begin{abstract}
Background - Hair loss is a dermatological disorder that has been recognized for more than $2000 \mathrm{yr}$. It is common throughout the world. The study of Yastimadhuk Tail Pratimarsha Nasya having nourished activities may give a new approach in the treatment of Khalitya (hair fall). Objectives - To Study the efficacy of Yastimadhuk Tail Pratimarsha Nasya in the management of Khalitya (hair fall). Material and Method- 60 patients participated in this clinical study carried out 7 day each over 91 days. The patient were divided into two groups, first group was treated with Yastimadhuk Tail Pratimarsha Nasya and second group was treated with control only. Both groups were subjected to various clinical sign and other parameter to evaluate antihairfall effect of nasya therapy with Yastimadhuk Tail. Result- The group which taken Yastimadhuk Tail Pratimarsha Nasya showed significant improvement in all clinical Keshapatan and Keshabhumikandu were observed with gradation .and objective parameters namely Visibility of scalp, Hair pull test, Number of hair approximately in included in the study when composed with control group. Hemogram done for estimation of $\mathrm{Hb} \%$ before and after treatment was correlated. Discussion - It is though that Yastimadhuk Tail which is Madhur,Snigdha,Guna decrease in Vata and Pitta. Madhur rasa have Bruhan, and Tarpan karma on hair roots which acts antihairfall. Snigdha guna of Tail give relief Keshakandu.Conclusion-Hence it can be concluded that the Yastimadhuk Tail Pratimarsha Nasya when used, it was efficient in treating Khalitya (hair fall) and showed significant relief $(\mathrm{p}<0.05)$ in symptoms within 3 month of treatment.
\end{abstract}

Keywords: Khalitya Yastimadhuk Tail, Pratimarsha Nasya, Bruhan, Tarpan karma.

Introduction

Khalitya(hair fall) is a disorder of hair in which there is hair loss more than average. It is a pittaj disease with anubandha of vata and kapha and is an urdhavjatrugat disorder. (1) Khalitya (hair fall) disease is mentioned in all the text under the heading "Kshudraroga" Therefore only their Samprapti and chikitsa is mentioned specially. (2) In Ayurveda classic, symptoms of alopecia correlate with Khalitya(hair fall) which is one of the major illnesses of the present generation. Hair fall is a physiological phenomenon if it occurs after the mid-forties but is considered disease if it arises, earlier. Alopecia which is the medical description literally means loss of hair and can have many causes. Hair falls occurs due to many predisposing factors like viz. modern day lifestyle, eating habits, pollutant stress, decreased immunity, hormonal imbalance, faulty hair care etc. Exposure to sunlight and pollution further worsen the health of hair. Improper diet factor, sedentary life style, malnutrition, sleep disturbances, systemic disease, local disease of scalps are leading to hair falls.

Generally people's uses different types of oil (chemical oil), shampoos, soap and pharmaceutical promotion are in the name of Saundarya Prasadhana to

*Corresponding Author:

Mamata Prataprao Tirankar

Assistant Professor,

Department Swasthavritta,

S.A.M.C.H, Indore

Email id: tirankarmamata@gmail.com solve the above problem.

The present study has been undertaken to manage the condition of Khalitya (hair fall) by Nasya treatment- which is one of the choices of management for its prime role in maintaining hair growth and preventing Khalitya (hair fall) (3). Administration of the medicines through nasal route is known as nasya (4). As this is the nearest root, the diseases related to head is best treated by this procedure. Medicated oil when dropped into the nostril in a small and specific dose is known as Pratimarsh Nasya. Dose is very important factor in any clinical procedure to get optimum efficacy of the therapy. So to decide minimum does of nasya here Pratimarsh Nasya type is selected for the management as its dose is minimal ( $2^{0}$ drops $)$ and even patients get afford its cost. (5)

According Charaka Pratimarsha Nasya is safe \& convenient to give to the patients as it does not produces any discomfort or complication and it also help in maintaining sama dosha. (6)In Tarpana Nasya, Pratimarsha Nasya may also be included because the main function of Pratimarsha Nasya is Tarpana of Shira. (7)

If nasya is done with tail which is medicated by drug having vatapittahara and keshya property will help in antihair loss definitely, Yastimadhuk tail having all its property \& it contains Yastimadhu, Amalaki, Godugdha, Til Tail which are easily available in the market and cost effective that's why it is selected for Nasya therapy in Khalitya(hair fall). (8) Considering all above benefits of Nasya an attempt was made to evaluate role of Pratimarsh Nasya on Khalitya (hair fall). 


\section{Aims and objective}

- To study the efficacy of Yashtimadhuk Tail Pratimarsh Nasya in the management of Khalitya (hair fall).

- To find safe \& effective remedy for Khalitya (hair fall).

\section{Materials and methods}

Study population

The patients complaining mainly of Khalitya hair fall were selected from Kayachikitsa OPD of Hospital irrespective of occupation, religion and prakruti.

\section{Sample size}

30 patient in each group were selected for this clinical study.

\section{Selection of cases}

Study was carried out from July 2013- July 2014. The patients coming to the OPD of Kayachikitsa were selected into the study on the basis of following criteria.

\section{Selection criteria}

The cases are selected as per signs and symptoms of Khalitya (hair fall)

\section{Diagnostic criteria}

Patients were diagnosed based on clinical feature of Khalitya(hair fall) like hair falls, roughness of hair, thinning of hair, itching of scalp.

\section{Inclusion criteria}

- Patient from age group 20-60 year were included having hair fall symptoms.

- Patient who are fit for Nasya karma procedure.

- History of hair falls irrespective of any disease.

Exclusion criteria

- Patient Having Alopecia Areata, Alopecia Totalis, Tinea Capitis, Traction Alopecia,

- Patients who are unfit for Nasyakarma

- ANC women and lactating mother.

- Patient suffering from malignancy \& systemic disease.

- Patient on chemotherapy.

The detailed clinical history and clinical examination including hair fall symptoms. Questionnaire was noted on a specially prepared Case Report Performa (CRF).

\section{Ethical Clearance}

Before starting the study the protocol was approved from the institutional Ethical committee (IEC), a well informed consent was obtained from every patient before enrolment into the study. They were also informed about the treatment given to them in the language they understand.

Group management

Patients included in the study were randomly divided into two groups.

Table. No.1: Description of the groups

\begin{tabular}{|c|c|c|}
\hline & $\begin{array}{l}\text { Group } \\
\text { Experimental Group }\end{array}$ & $\begin{array}{l}\text { Group } \quad \text { B }- \\
\text { Control Group }\end{array}$ \\
\hline Drug & $\begin{array}{l}\text { Yashtimadhuk Taila } \\
\text { Nasya }\end{array}$ & \multirow{3}{*}{ No Treatment } \\
\hline$\overline{\text { Dose }}$ & $\begin{array}{l}\text { Daily two drop in each } \\
\text { nostril. }\end{array}$ & \\
\hline$\overline{\text { Kala }}$ & $\begin{array}{lll}\text { At early } & \text { morning \& } \\
\text { evening } & \text { as per } \\
\text { prakruti. } & & \\
\end{array}$ & \\
\hline Duration & 7 days till 90 days $(9)$ & $\begin{array}{l}7 \text { days till } 90 \\
\text { days }\end{array}$ \\
\hline Follow up & 7 Days & 7 Days \\
\hline
\end{tabular}

Assessment Criteria

Subjective Parameters

For subjective parameters grading was done for the symptoms like keshapatan, keshabhumikandu as follows.

\section{In Keshapatan}

Normal hair loss scored as

Average hair loss scored as

Above average hair loss scored as

Baldness scored as

0

1

2

3

\section{In Keshabhumikandu}

No itching scored as

Itching of scalp rarely scored as

Itching off and on scored as

Continuous itching scored as

0

1

2

3

Table. No.2: Scoring of Objective Parameters

\begin{tabular}{|l|l|}
\hline Description & Score \\
\hline Visibility of scalp & \\
\hline Complete hair grown (75\%-100\%) & 0 \\
\hline $\begin{array}{l}\text { Moderate Partial grow up of hair } \\
\text { ( } \geq 50 \% \text { of affected area) }\end{array}$ & 1 \\
\hline $\begin{array}{l}\text { Partial grow up of hair ( } \geq 25 \% \text { of } \\
\text { affected area) }\end{array}$ & 2 \\
\hline No hair grow in affected area & 3 \\
\hline Hair count & 0 \\
\hline Number of hair fall $<10$ & 1 \\
\hline Number of hair fall 11- 40. & 2 \\
\hline Number of hair fall 41 -70. & 3 \\
\hline Number of hair fall $>70$. & 0 \\
\hline Hair Pull Test & 1 \\
\hline $\begin{array}{l}\text { Normally less than three hairs come out } \\
\text { with each pull from each area of scalp. }\end{array}$ & 0 \\
\hline $\begin{array}{l}\text { If more than 10 hairs come out with } \\
\text { every pull }\end{array}$ & 1 \\
\hline
\end{tabular}

Examination of patient

General examination of patient was done recorded in specially prepared case record form (CRF) before and after treatment.

In this clinical study 60 patients were enrolled as per criteria for selections \& randomly divided into two groups. Viz. Experimental and control group. 
Drug source

All the drugs are identified by the department of Dravyagunvidnyan \& Rasshashtra for preparation of Yashtimadhuk Tail.

Contents in Yashtimadhuk Tail are Yashtimadhu, Amalaki, Godughdha \& Til tail.

\section{Method of preparation of Yashtimadhuk Tail: (8)}

Firstly, Yashtimadhu \& Amalaki churna were taken in proportion $125 \mathrm{gm}$ each, then it boiled into 1 litre of water to make it proper $k w a t h$, it boiled up to it become $1 / 4$ of original volume. After that 4 litre milk was added into prepared kwath \& finally 1 litre Sesamum oil added into whole mixture \& processed on mandagni (on heat) till the mixture get mixed properly in the form oil till it got proper Sneha siddhi Lakshan.

After finished this procedure the prepared oil is cooled, filtered properly \& preserved for the use of Nasya. (Table No.3)

\section{Procedure \& Duration of Nasya(9)}

Nasya was given in the form of Pratimarsha nasya i.e. 2 drop of Yashtimadhuk Tail were instilled in each nostril twice daily from 7 days till 90 days in morning and evening. All the patients were provided 50 $\mathrm{ml}$ Yashthimadhuk Tail bottle as and when required.

\section{Follow up}

Patients were asked to give the follow weekly till the 90 days.

\section{Data Analysis}

Statistical evaluation of the data assessed on the basis of both subjective \& objective criteria by applying Wilcoxon Signed Rank Test \& Mann Whitney Test for comparative effect of Nasya in subjective \& objective parameter. Thus analysis was calculated before \& after treatment in group A and group B. Finally overall effect of treatment and also the comparative effect of treatment between group A and group B were concluded statistically.

Table. No.3: Yashtimadhuk Tail Analysis Report

\begin{tabular}{|l|l|l|}
\hline Sr. No. & Test Name & Results Obtained \\
\hline 1 & Description & Medicated Oil slightly hazy yellowish liquid \\
\hline 2 & Odor & Strong \\
\hline 3 & Feel & Oily \\
\hline 4 & Specific Gravity @ RT & $0.9528 \mathrm{gm} / \mathrm{ml}$ \\
\hline 5 & Moisture Content & $<0.1 \%$ \\
\hline 6 & Saponification Value & 178.10 \\
\hline 7 & Iodine Value & 83.90 \\
\hline 8 & Acid Value & 02.33 \\
\hline 9 & Refractive Index & 1.4681 \\
\hline 10 & Viscosity & $36.4 \mathrm{cps}$ \\
\hline
\end{tabular}

All above tests are performed on standard method \& protocol.

\section{Result}

In this study 60 patients of Khalitya (hair fall) were studied and selected as per criteria of selection randomly irrespective of religion, socio-economic status. All these patients were diagnosed with the help of criteria of diagnosis. Specially designed Performa was used. Patients attending O.P.D of the hospital were examined prior to the start of treatment with respect to the Performa. All these values were termed as before treatment values. (B.T)

After complete examination therapy was started. Experimental group was treated with Yashtimadhuk Tail \& it is considered as group-A. While in control group no treatment allocated and considered as group-B. After completion of therapy all values of these investigations and examinations were recorded and were termed as after treatment (AT).

All these observations were statistically analysed and results obtained are presented in Table.4.

Table No.4: Showing Comparison between Two Group w.r.t Symptoms Score of 60 Patients of Khalitya By Wilcoxon-Mann-Whitney Test

\begin{tabular}{|c|c|c|c|c|c|c|c|}
\hline \multirow[t]{2}{*}{ No } & \multirow[t]{2}{*}{ Symptoms } & \multicolumn{2}{|c|}{ Mean \pm SD } & & & \multirow[t]{2}{*}{$\overline{S E}$} & \multirow[t]{2}{*}{ P Value } \\
\hline & & Gr-A & Gr-B & $\mathbf{U}^{\prime}$ & $\overline{\mathbf{U}}$ & & \\
\hline$A$. & \multicolumn{7}{|l|}{ Subjective Criteria } \\
\hline & Keshapatan & $0.83 \pm 0.53$ & $0.20 \pm 0.55$ & 690 & 210 & 0.096 & $<0.0005$ \\
\hline & Keshabhumikandu & $0.46 \pm 0.68$ & $0.10 \pm 0.54$ & 574 & 325 & 0.12 & $>0.05$ \\
\hline$\overline{\mathbf{B}}$ & \multicolumn{7}{|l|}{ Objective Criteria } \\
\hline 1 & Visibility of scalp & $0.93 \pm 0.69$ & $0.66 \pm 0.54$ & 359 & 541 & 0.1739 & $>0.05$ \\
\hline 2 & Number of fallen hairs & $0.83 \pm 0.53$ & $0.26 \pm 0.58$ & 662 & 238 & 0.09 & $<0.005$ \\
\hline 3 & Hair pull Test & $0.53 \pm 0.50$ & $0.06 \pm 0.40$ & 644 & 256 & 0.09 & $<0.005$ \\
\hline
\end{tabular}

\section{Discussion}

In this trial drug, Yastimadhu was main constituent which having madhur vipak and sheet veerya \& due to this properties it is vatapittahara. (10) Additionally Aamalaki having amla rasa, madhur vipak \& sheet veerya so it 
acts as tridosha shamak. (11) Til tail is madhur ushna and tridoshshamak. (13)Godughdha \& Aamalaki both possess the properties of rasayana. (14) So the ingredient of Yashtimadhuk tail are having madhur rasa, guru, Laghu, Snigdha, guna whereas madhur vipak, tridosha shamak specially pitta vata shamak properties. The drugs are also having the other properties like keshya, rasayana and keshavardhan. The laghu \& snigdha properties would act on the vitiation of the kapha \& vata dosha respectively whereas sheet veerya \& madhur vipak would act on pitta dosha, the ushna veerya would act on the vitiation of kapha. Sheet \& madhur vipak would act on pittadosh. The ushna veerya \& snigdhatva would act in liquefying the dried kapha in the pores of the scalp locally to remove the obstruction.

\section{Conclusion}

The outcome in terms of symptomatically improvements was significant in experimental group compare to control group. However the problem of Khalitya (hairs fall) is chronic in nature but not serious disorders. There is no hampering of quality of life even if not treated but if we care about beauty one should be careful maintain the health of hairs in terms of diet as well as management of hair care.

However, I do not claim my topic of study is a distinguished one and the outcome credited through my work is a milestone in the field of research, but the small work, which has been carried out sincerely is a beam of rays and may shed light in the management of Khalitya (hair fall).

\section{Reference}

1. Sharma A R. Sushruta Samhita of Acharya Sushruta. Reprint edition.Varanasi; Chaukhamba Surbharati Prakashan publishers; 2009. 558p.

2. Tripathi R D. Charak Samhita of Acharya Charaka. Reprint edition.Varanasi; Chaukhamba Sanskrit Pratisthan publishers; 2006.647p.
3. Tripathi R D. Charak Samhita of Acharya Charaka. Reprint edition.Varanasi Chaukhamba Sanskrit Pratisthan publishers; 2005.96p.

4. Sharma A R. Sushruta Samhita of Acharya Sushruta. Reprint edition.Varanasi; Chaukhamba Surbharati Prakashan publishers; 2009.495p.

5. Tripathi R D. Charak Samhita of Acharya Charaka. Reprint edition.Varanasi; Chaukhamba Sanskrit Pratisthan publishers; 2006.1298p.

6. Sharma A R. Sushruta Samhita of Acharya Sushruta. Reprint edition.Varanasi; Chaukhamba Surbharati Prakashan publishers; 2009.500p.

7. Tripathi R D. Charak Samhita of Acharya Charaka. Reprint edition.Varanasi;Chaukhamba Sanskrit Pratisthan publishers; $2006.1187 \mathrm{p}$.

8. Tripathi B. Sharangadhar Samhita of Acharya Sharangadhara. Reprint edition.Varanasi; Chaukhamba Surbharati Prakashan publishers; 2008.240p.

9. Tripathi B. Asthanga Hridaya of Acharya Vagbhata. Reprint edition.Varanasi; Chaukamba Sanskrit Sansthan publishers; 2007.246p.

10. Tripathi R D. Charak Samhita of Acharya Charaka. Reprint edition.Varanasi; Chaukhamba Sanskrit Pratisthan publishers; 2005.399p.

11. Sharma A R. Sushruta Samhita of Acharya Sushruta. Reprint edition.Varanasi; Chaukhamba Surbharati Prakashan publishers; 2009.406p.

12. Tripathi R D. Charak Samhita of Acharya Charaka. Reprint edition.Varanasi; Chaukhamba Sanskrit Pratisthan publishers; 2006.418p.

13. Mishra B S. Bhavaprakash Nighantu of Bhavamishra. $11^{\text {th }}$ edition. Varanasi; Chaukhamba Sanskrit Bhavan publishers; 2007.758p.

14. Tripathi R D. Charak Samhita of Acharya Charaka. Reprint edition.Varanasi; Chaukhamba Sanskrit Pratisthan publishers; 2006.418p. 